\title{
PERBEDAAN HASIL BELAJAR IPA BIOLOGI MENGGUNAKAN MODEL RECIPROCAL LEARNING DAN MODEL PROBLEM BASED LEARNING
}

\section{BIOLOGICAL SCIENCE LEARNING OUTCOMES DIFFERENCES USING RECIPROCAL LEARNING AND PROBLEM BASSED LEARNING MODEL}

\author{
Febrina Amaliya Rha'ifa ${ }^{1}$, Khairuddin ${ }^{2 *}$, I Wayan Merta $^{2}$ \\ ${ }^{1}$ Mahasiswa Pendidikan Biologi, Jurusan Pendidikan MIPA, Fakultas Keguruan dan Ilmu Pendidikan, \\ Universitas Mataram. Jalan Majapahit No. 62 Mataram, 83125. Indonesia \\ ${ }^{2}$ Program Studi Pendidikan Biologi, Jurusan Pendidikan MIPA, Fakultas Keguruan dan Ilmu Pendidikan, \\ Universitas Mataram. Jalan Majapahit No. 62 Mataram, 83125. Indonesia \\ *Email: khairuddin644@gmail.com
}

Diterima: 25 Januari 2019. Disetujui: 09 Februari 2019. Dipublikasikan: 31 Maret 2019

\begin{abstract}
Abstrak. Penelitian ini bertujuan untuk mengetahui perbedaan hasil belajar IPA Biologi antara siswa yang belajar menggunakan model Reciprocal Learning (RL) dan siswa yang belajar menggunakan model Problem Based Learning (PBL) di kelas VII SMP Negeri 20 Mataram tahun ajaran 2016/2017. Jenis penelitian ini adalah penelitian komparatif. Desain penelitian yang digunakan adalah pretest-postest non-control group design. Populasinya adalah seluruh siswa kelas VII SMP Negeri 20 Mataram. Penentuan sampel dilakukan dengan teknik simple random sampling dan diperoleh kelas VII B sebagai kelas eksperimen I dan kelas VII D sebagai kelas eksperimen II. Instrumen yang digunakan untuk mengukur hasil belajar adalah objective test. Data yang diperoleh dianalisis dengan uji-t polled varians dengan taraf signifikansi $5 \%$. Data yang diuji dengan uji-t tersebut adalah data gain score. Hasil uji-t untuk data hasil belajar kognitif didapatkan bahwa thitung $>$ ttabel yakni $2,15>2.02$. Hasil analisis data menunjukkan terdapat perbedaan hasil belajar siswa menggunakan model Reciprocal Learning (RL) dan Problem Based Learning (PBL) di SMP Negeri 20 Mataram tahun ajaran 2016/2017.
\end{abstract}

Kata Kunci: Model Pembelajaran Reciprocal Learning (RL), Model Pembelajaran Problem Based Learning (PBL), Hasil belajar.

\begin{abstract}
This research aimed to determine difference in learning achievement of IPA Biology VII grade students using Reciprocal Learning (RL) model and Problem Bassed Learning (PBL) model at SMP Negeri 20 Mataram academic year 2016/2017. Type of this research was comparative research. Pretest-posttest noncontrol group design was used as design of this research. The population of this research was VII grade students of SMP Negeri 20 Mataram. The samples in this research used simple random sampling that has chosen VII B as experiment class 1 and VII D as experiment class 2. The instrument that used for this research is objective test. The data obtained were analyzed by t-test polled variance with significance level of $5 \%$. The data tested by the t-test is the gain score data. The result of t-test for cognitive learning data found tcount $>$ ttable that is $2.15>$ 2.02. The result of data analysis shows that there are differences of student learning achievement using Reciprocal Learning (RL) model and Problem Based Learning (PBL) model in SMP Negeri 20 Mataram academic year 2016/2017.
\end{abstract}

Keywords: Reciprocal Learning Model, Problem Based Learning Model, Learning Achievement.

\section{PENDAHULUAN}

Pendidikan merupakan faktor utama kemajuan suatu bangsa. Dunia pendidikan memiliki tanggung jawab dan kontribusi penuh terhadap perkembangan manusia untuk menjadi manusia seutuhnya yang kompeten dan berakhlak mulia. Karena itu perubahan dan rekonstruksi menuju arah yang lebih baik senantiasa dilakukan dalam dunia pendidikan seiring dengan perkembangan zaman yang terus berlangsung [1]

Kegiatan belajar mengajar merupakan inti pendidikan, akan lebih efektif apabila siswa mendalami dan menghayati pengalamannya sebagai hasil belajar yang merupakan bagian dari dirinya. Pada proses pembelajaran di kelas, terdapat beberapa komponen yang dapat mempengaruhi hasil belajar siswa. Komponenkomponen tersebut antara lain guru, siswa, sarana dan prasarana, dan strategi pembelajaran serta keadaan atau kondisi kelas [2].

Pembelajaran IPA khususnya Biologi merupakan salah satu pembelajaran yang mengkaji tentang makhluk hidup dan komponen penyusun kehidupan. Pembelajaran ini memerlukan kegiatan penyelidikan atau eksperimen yang melibatkan keterampilan proses. Sehingga dalam proses 
pembelajaran harus menggunakan model pembelajaran yang tepat dan bervariasi. Penggunaan model pembelajaran yang bervariasi akan melatih siswa dalam berfikir kritis dan mengasah keterampilan serta memecahkan suatu permasalahan yang ada dalam kehidupan seharihari [3].

Berdasarkan hasil observasi yang dilakukan di SMP Negeri 20 Mataram pada kelas VII diketahui bahwa permasalahan yang muncul saat proses pembelajaran Biologi berlangsung adalah 1). Pada saat proses pembelajaran berlangsung, perhatian siswa tidak terpusat pada kegiatan pembelajaran, 2). Siswa kurang berminat dengan pembelajaran Biologi, 3). Model pembelajaran yang sering diterapkan dalam pembelajaran Biologi kurang bervariasi. Guru hanya menggunakan beberapa model pembelajaran dalam proses pembelajaran di kelas. Model yang sering digunakan adalah model pembelajaran kooperatif seperti model Think Pair Share (TPS), Student Team Achievement (STAD), dan model pembelajaran konvensional. Dalam pelaksanaan model pembelajaran di kelas, guru dominan menggunakan model pembelajaran konvensional dengan metode ceramah, 4). Siswa kurang aktif dalam proses belajar mengajar. Hal-hal tersebut menyebabkan hasil belajar Biologi siswa menjadi menurun, dapat dilihat dari nilai ulangan harian siswa yang berkisar antara 50 sampai $80.80 \%$ siswa memiliki nilai ulangan harian dibawah kriteria ketuntasan minimal (KKM). Salah satu upaya untuk memperbaiki kondisi ini adalah dengan menerapkan model pembelajaran yang dapat menarik perhatian siswa sehingga siswa memiliki keinginan untuk belajar dan dapat berinteraksi antar sesama siswa maupun dengan guru.

Reciprocal Learning (RL) merupakan salah satu model pembelajaran yang memiliki empat strategi yaitu merangkum, menyusun pertanyaan, mengklarifikasi dan memprediksi. Dalam strategi merangkum, memberikan kesempatan kepada siswa untuk mengidentifikasi dan menguraikan dengan kata-kata sendiri [4]. Membuat pertanyaan dan memprediksi jawabannya merupakan suatu bagian dalam kontruktivisme. Di mana dalam teori kontruktivisme menekankan pada proses belajar mengajar yang berpusat pada siswa. Siswa yang harus aktif mengembangkan pengetahuan siswa, siswa harus dimotivasi untuk membaca, menggali dan mengkonstruksi pengetahuan siswa itu sendiri. Pada tahap mengklarifikasi memberikan kesempatan kepada siswa untuk menuliskan hal-hal yang tidak jelas dalam teks bacaan sehingga siswa bisa lebih mandiri. Metode ini memberikan siswa kebebasan untuk mengembangkan kemampuannya sehingga tidak tergantung kepada [5-7].
Model Problem Based Learning (PBL) adalah model pembelajaran dengan pendekatan pembelajaran siswa pada masalah autentik sehingga siswa dapat menyusun pengetahuannya sendiri, menumbuh kembangkan keterampilan yang lebih tinggi dan inquiry, memandirikan siswa dan meningkatkan kepercayaan diri. PBL menjadikan masalah nyata sebagai pemicu bagi proses belajar beserta didik sebelum mereka mengetahui konsep formal. Siswa secara kritis mengidentifikasi informasi strategi yang relevan serta melakukan penyelidikan untuk menyelesaikan masalah tersebut. PBL juga dimaksudkan untuk mengembangkan kemandirian belajar dan keterampilan sosial dapat terbentuk ketika siswa berkolaborasi untuk mengidentifikasi informasi, strategi dan sumber belajar yang relevan untuk menyampaikan masalah [8-12].

Berdasarkan uraian tersebut, maka perlu dilakukan penelitian tentang perbedaan perbedaan hasil belajar IPA Biologi siswa kelas VII menggunakan model Reciprocal Learning (RL) dan model Problem Based Learning (PBL) di SMP Negeri 20 Mataram tahun ajaran 2016/2017.

\section{METODE PENELITIAN}

Penelitian ini adalah penelitian kompratif. Populasi dalam penelitian ini adalah seluruh siswa kelas VII SMP Negeri 20 Mataram tahun ajaran 206/2017. Sampel penelitian ditentukan melalui teknik simple random sampling. Sampel penelitian yang di dapatkan yaitu kelas VII B sebagai kelas eksperimen 1 menggunakan model Reciprocal Learning (RL) dan kelas VII D sebagai kelas eksperimen 2 menggunakan model Problem Based Learning (PBL). Rancangan penelitian yang digunakan adalah pre-test post-test non-control group design. Data yang dikumpulkan meliputi hasil belajar kognitif didapatkan dari tes pilihan ganda dan hasil belajar afektif dan psikokmotorik dari rubrik peniliaan afektif dan psikomotorik. Data hasil belajar kognitif yang telah diperoleh kemudian dianalisis menggunakan uji statistik. Analisis data diawali dengan uji normalitas dan homogenitas. Data yang dianalisis dengan uji-t adalah data gain score hasil belajar kognitif siswa.

\section{HASIL DAN PEMBAHASAN \\ Hasil Penelitian}

Pre-test yang telah dilakukan pada kelas VII B yang menggunakan model Reciprocal Learning (RL) diperoleh nilai terendah 38 dan nilai tertinggi 66 dengan nilai rata-rata 50,62. Sedangkan untuk kelas VII D yang menggunakan model Problem Based Learning (PBL) diperoleh nilai terendah siswa adalah 41 dan nilai tertinggi adalah 72, dengan nilai rata-rata 55,19. Berdasarkan data pretest tersebut dapat dilihat bahwa hasil belajar kedua kelas menunjukkan nilai rata-rata yang masih 
rendah sebelum diberikan pembelajaran dengan model Reciprocal Learning (RL) dan Problem Based Learning (PBL). Setelah dilakukan pembelajaran menggunakan model Reciprocal Learning (RL) dan Problem Based Learning (PBL), terjadi peningkatan hasil belajar yang dapat dilihat dari hasil -post-test. Pada kelas VII B yang menggunakan model Reciprocal Learning (RL) diperoleh nilai terendah 62 dan nilai tertinggi 86 dengan nilai rata-rata 74,43 , sedangkan pada kelas VII D diperoleh nilai terendah siswa adalah 69 dan nilai tertinggi adalah 93, dengan nilai rata-rata 84,33 . Data hasil belajar kedua kelas sampel dapat dilihat pada Tabel 1 .

Tabel 1. Data Hasil Belajar Kognitif

\begin{tabular}{lllll}
\hline Hasil & \multicolumn{2}{l}{ Kelas eksperimen I (RL) } & \multicolumn{2}{l}{ Kelas eksperimen II (PBL) } \\
\cline { 2 - 5 } & Pre-test & Post-test & Pre-test & Post-test \\
\hline Nilai tertinggi & 66 & 86 & 41 & 63 \\
Nilai terendah & 38 & 62 & 72 & 69 \\
Rata-rata & 50,62 & 74,43 & 55,19 & 29,33 \\
Selisih & & 23,81 & \multicolumn{2}{c}{29,14} \\
\hline
\end{tabular}

Berdasarkan data yang diperoleh dari pelaksanaan pre-test dan post-test dari kedua kelas, maka diketahui bahwa peningkatan nilai hasil belajar kelas yang menggunakan model Problem Based Learning (PBL) lebih tinggi dibandingkan kelas yang menggunakan model Reciprocal Learning (RL). Hasil tersebut terlihat pada selisih peningkatan nilai rata-rata kelas Problem Based Learning (PBL) lebih tinggi daripada Reciprocal Learning (RL), yaitu 29,14>23,81.

Hasil analisis penilaian afektif secara klasikal diperoleh dari kelas yang menggunakan model Reciprocal Learning (RL) dan model Problem Based Learning (PBL) diperoleh persentase nilai afektif pada kelas VII B yang menggunakan model Reciprocal Learning (RL) sebanyak $0 \%$ berkategori sangat rendah, 9,52\% berkategori rendah, 76,19\% kategori tinggi, dan 14,29\% berkategori sangat tinggi. Pada kelas VII D yang menggunakan model Problem Based Learning (PBL) sebanyak $0 \%$ berkategori sangat rendah, $0 \%$ kategori rendah, 71,43\% berkategori tinggi, dan 28,57\% berkategori sangat tinggi. Perbandingan nilai afektif pada kedua model tersebut dapat dilihat pada tabel berikut. Perbandingan nilai afektif pada kedua model tersebut dapat dilihat pada Tabel 2.

Tabel 2. Perbandingan hasil belajar afektif

\begin{tabular}{|c|c|c|c|c|c|}
\hline \multirow[t]{3}{*}{ Rentang } & \multirow[t]{3}{*}{ Kategori } & \multicolumn{4}{|c|}{ Hasil Penelitian } \\
\hline & & \multicolumn{2}{|c|}{ Kelas RL } & \multicolumn{2}{|c|}{ Kelas PBL } \\
\hline & & $\begin{array}{l}\text { Jumlah } \\
\text { siswa }\end{array}$ & $\begin{array}{l}\text { Presen } \\
\text { tase }(\%)\end{array}$ & $\begin{array}{l}\text { Jumlah } \\
\text { siswa }\end{array}$ & $\begin{array}{l}\text { Presen tase } \\
(\%)\end{array}$ \\
\hline $9<x \leq 20$ & Sangat rendah & 0 & 0 & 0 & 0 \\
\hline $21<x \leq 30$ & Rendah & 2 & 9,52 & 0 & 0 \\
\hline $31<x \leq 40$ & Tinggi & 16 & 76,19 & 15 & 71,43 \\
\hline $41<x \leq 50$ & Sangat tinggi & 3 & 14,29 & 6 & 28,57 \\
\hline
\end{tabular}

Berdasarkan Tabel 2 di atas, secara deskriptif dapat dikatakan bahwa jumlah siswa yang memiliki nilai afektif sangat tinggi pada kelas yang menggunakan model Problem Based Learning (PBL) lebih banyak daripada kelas yang menggunakan model Reciprocal Learning (RL), yaitu 28,57 \% dan 14,29 \%. Sedangkan siswa dengan kategori afektif tinggi pada kelas yang menggunakan model Reciprocal Learning (RL) lebih banyak daripada kelas yang menggunakan model Problem Based Learning (PBL), yaitu 76,19 $\%$ dan $71,43 \%$. Sedangakan siswa dengan nilai afektif rendah hanya ditemukan pada kelas yang menggunakan model Reciprocal Learning (RL) yaitu $9,52 \%$. Hal tersebut menunjukkan bahwa kelas yang menggunakan model Problem Based Learning (PBL) memiliki nilai afektif lebih tinggi terhadap nilai afektif siswa yang menggunakan model Reciprocal Learning (RL).

Penilaian hasil belajar psikomotorik pada kelas yang menggunakan model Reciprocal Learning (RL) diperoleh $0 \%$ berkategori sangat rendah, $23,81 \%$ berkategori rendah, $38,10 \%$ berkategori tinggi dan sangat tinggi. Untuk kelas yang menggunakan model Problem Based Learning (PBL) diperoleh $0 \%$ berkategori sangat rendah, $23,81 \%$ berkategori rendah, 52,38\% berkategori tinggi, dan 23,81\% berkategori sangat tiggi. Perbandingan nilai psikomotorik dapat dilihat pada Tabel 3. 
Tabel 3. Perbandingan hasil belajar psikomotorik

\begin{tabular}{llllll}
\hline Rentang & Kategori & \multicolumn{3}{c}{ Hasil Penelitian } \\
\cline { 3 - 6 } & & \multicolumn{2}{c}{ Kelas RL } & \multicolumn{2}{c}{ Kelas PBL } \\
\cline { 3 - 6 } & & Jumlah siswa & Presentase (\%) & Jumlah siswa & Presentase (\%) \\
\hline $9<\mathrm{x} \leq 20$ & Sangat rendah & 0 & 0 & 0 & 0 \\
$21<\mathrm{x} \leq 30$ & Rendah & 5 & 23,81 & 5 & 23,81 \\
$31<\mathrm{x} \leq 40$ & Tinggi & 8 & 38,10 & 11 & 52,38 \\
$41<\mathrm{x} \leq 50$ & Sangat tinggi & 8 & 38,10 & 5 & 23,81 \\
\hline
\end{tabular}

Berdasarkan Tabel 3 di atas, dapat diketahui bahwa presentase jumlah siswa dengan kategori psikomotorik sangat tinggi pada kelas yang menggunakan model Reciprocal Learning (RL) lebih banyak dibandingkan kelas kelas yang menggunakan model Problem Based Learning (PBL), yaitu $38,10 \%$ dan $23,81 \%$. Jumlah siswa berkategori tinggi lebih banyak pada kelas yang menggunakan model Problem Based Learning (PBL) dibandingkan kelas yang menggunakan model Reciprocal Learning (RL), yaitu 38,10\% dan 52,38\%. Untuk kategori rendah kedua kelas tersebut memiliki jumlah persentase yang sama yaitu $23,81 \%$. Data tersebut menunjukkan bahwa kedua model memberikan pengaruh yang hampir sama terhadap peningkatan psikomotorik siswa.

Pengujian hipotesis untuk mengetahui ada tidaknya perbedaan hasil belajar antara kelas yang menggunakan model Reciprocal Learning (RL) dan model Problem Based Laerning (PBL) dianalisis menggunakan uji t. Data hasil belajar kognitif yang dianalisis menggunakan uji-t ialah hasil gain score atau selisih dari nilai post-test dan pre-test siswa. Hasil uji normalitas dan homogenitas gain score, didapatkan bahwa $\chi 2$ hitung $<\chi 2$ tabel yaitu $3,47<9,49$ maka data dinyatakan terdistribusi normal. Hasil uji homogenitas gain score pada kedua kelas didapatkan bahwa Fhitung $<$ Ftabel yaitu $0,87<$ 2,12 maka data kedua kelas dinyatakan homogen. Hasil uji t dengan taraf kesalahan 0.05, diperoleh nilai thitung $>$ ttabel, yaitu 2,15 $>2,02$ yang berarti menolak H0 dan menerima Ha. Hal ini menunjukkan bahwa ada perbedaan hasil belajar IPA Biologi siswa kelas VII yang menggunakan model Reciprocal Learning (RL) dan model Problem Based Learning (PBL) di SMP Negeri 20 Mataram tahun ajaran 2016/2017.

\section{Pembahasan}

Model pembelajaran yang digunakan dalam penelitian ini adalah model Reciprocal Learning (RL) dan model Problem Based Learning (PBL). Jenis penelitian yang dilakukan adalah penelitian komparatif. Penelitian ini dilakukan untuk melihat perbedaan hasil belajar IPA Biologi siswa yang menggunakan model Reciprocal Learning (RL) dan model Problem Based Learning (PBL) yang sudah dilaksanakan pada kelas VII di SMP Negeri 20 Mataram. Kegiatan pembelajaran pada kelas eksperimen I menggunakan model Reciprocal Learning (RL) sedangkan untuk kelas eksperimen II menggunakan model Problem Based Learning (PBL).

Berdasarkan hasil tes yang didapatkan oleh siswa dikelas eksperimen I nilai ratarata pada data pretest adalah 50,62 dan pada data post-test sebesar 74,43 . Sedangkan pada kelas eksperimen II nilai rata-rata data pre-test sebesar 55,19 dan pada data post-test sebesar 84,43. Data ini menunjukkan bahwa kedua model tersebut dapat meningkatan hasil belajar IPA Biologi siswa. Untuk hasil uji hipotesis data hasil belajar siswa menunjukkan nilai thitung sebesar 2,15 lebih besar dari ttabel yaitu 2,02 $(2,15>2,02)$, maka $\mathrm{H0}$ ditolak dan $\mathrm{Ha}$ diterima yang berarti bahwa ada perbedaan hasil belajar IPA Biologi siswa kelas VII yang menggunakan model Reciprocal Learning (RL) dengan model Problem Based Learning (PBL) di SMP Negeri 20 Mataram tahun ajaran 2016/2017.

Dari data yang diperoleh menunjukkan bahwa model Problem Based Learning (PBL) memberikan peningkatan hasil belajar yang lebih tinggi daripada model Reciprocal Learning (RL). Selisih rata-rata kelas yang menggunakan model Problem Based Learning (PBL) adalah 29,14, selisih rata-rata tersebut lebih tinggi dibandingkan dengan kelas yang menggunakan model Reciprocal Learning (RL) yaitu 23,81. Hasil ini sejalan dengan penelitian yang dilakukan oleh peneliti sebelumnya [11, 12, 13], yang menyatakan model Problem Based Learning (PBL) lebih baik daripada model Reciprocal Learning (RL) dalam meningkatkan hasil belajar siswa. Model Problem Based Learning (PBL) memberikan kekuatan bagi siswa dalam hal kemampuan berpikir mereka, karena berorientasi pada proses dan menekankan keterlibatan mahasiswa secara aktif baik fisik maupun mental dengan memecahkan permasalahan-permasalahan yang dikonstruksi dalam bentuk pertanyaan dan dipecahkan melalui kerja kelompok.

Pada proses pembelajaran menggunakan model Problem Based Learning (PBL), siswa sangat antusias dalam mengemukakan pendapat mereka di dalam kelompok saat diskusi untuk menyelesaikan masalah yang diberikan oleh guru. Hal tersebut menyebabkan proses pembelajaran menjadi tidak monoton, karena peserta didik dituntut mencari sendiri jawaban dari pertanyaanpertanyaan yang diberikan guru dan 
kemudian didiskusikan dalam kelompok sehingga peserta didik lebih memahami materi yang diajarkan. Model pembelajaran Problem Based Learning (PBL) ini berdampak baik terhadap peningkatan penguasaan konsep peserta didik dan terjalin interaksi yang baik antar peserta didik, sehingga proses pembelajaran lebih menyenangkan.

Hasil pengamatan untuk kelas yang menggunakan model pembelajaran Reciprocal Learning (RL) menunjukkan proses pembelajaran dan hasil belajar yang cukup baik. Tetapi apabila dibandingkan dengan model pembelajaran Problem Based Learning (PBL), hasil belajar ranah kogitif siswa yang menggunakan model Reciprocal Learning (RL) lebih rendah. Hal ini dapat disebabkan karena dalam proses pembelajaran siswa memiliki beberapa kendala. Kendala utama yang dialami siswa yaitu pada tahap membuat pertanyaan, dimana pada tahap ini siswa masih sulit untuk merumuskan pertanyaan yang dibuat sendiri. Selain itu, kegiatan tanya jawab hanya dikuasai oleh siswa yang berani mengungkapkan pendapat saja sedangkan siswa yang pasif cenderung diam.

Penggunaan model pembelajaran baik pada kelas yang menggunakan model Reciprocal Learning (RL) dan pada kelas yang menggunakan model Problem Based Learning (PBL) juga mempengaruhi sikap (afektif) dan keterampilan (psikomotorik) siswa. Berdasarkan hasil analisis penilaian afektif dan psikomotorik kelas, didapatkan bahwa kedua model tersebut memberikan dampak yang positif dalam meningkatkan hasil belajar siswa pada ranah afektif dan psikomotorik. Pada hasil belajar afektif, jumlah siswa dengan kategori afektif sangat tinggi pada kelas yang menggunakan model Problem Based Learning (PBL) jauh lebih banyak dibandingkan dengan kelas yang menggunakan model Reciprocal Learning (RL). Kelebihan-kelebihan yang dimiliki oleh model Problem Based Learning (PBL) dalam mempengaruhi sikap dan keterampilan belajar siswa antara lain meningkatkan sikap tanggung jawab, kerjasama, dan mengembangkan keterampilan siswa dalam diskusi serta memecahkan masalah pada proses belajar. Hal ini senada dengan penelitian [14] yang menunjukkan bahwa pada hasil belajar ranah afektif dan psikomotorik didapatkan nilai rata-rata kelas yang menggunakan model Problem Based Learning (PBL) lebih baik dibandingkan dengan kelas yang menggunakan model Reciprocal Learning (RL).

\section{KESIMPULAN.DAN SARAN Kesimpulan}

Berdasarkan hasil penelitian dan pembahasan, dapat disimpulkan bahwa ada perbedaan hasil belajar IPA Biologi antara siswa yang belajar menggunakan model Reciprocal
Learning (RL) dengan siswa yang belajar menggunakan model Problem Based Learning (PBL) di SMP Negeri 20 Mataram. Pernyataan ini dibuktikan dari hasil analisis data, dimana thitung $>$ ttabel yaitu 2,15>2,02 dengan taraf signifikan 5\%.

\section{Saran}

1. Bagi guru IPA penerapan model Reciprocal Learning (RL) dan Problem Based Learning (PBL) dapat dijadikan sebagai alternatif dalam proses pembelajaran, khususnya mata pelajaran IPA Biologi.

2. Bagi peneliti selanjutnya, model Reciprocal Learning (RL) dan Problem Based Learning (PBL) dapat dicoba untuk diterapkan pada materi pelajaran serta pada jenjang pendidikan yang lain sesuai dengan kurikulum yang berlaku.

\section{DAFTAR PUSTAKA}

[1]. Sudarwan, D. 2011. Pengantar Kependidikan. Bandung: Alfabeta

[2]. Aunurrahman. 2011. Belajar dan Pembelajaran. Edisi ke-5. Bandung: Alfabeta.

[3]. Trianto. 2007. Model-model Pembelajaran Inovatif Berorientasi Konstruktivistik. Jakarta: Prestasi Pustaka.

[4]. Efendi, N. 2013. Pengaruh pembelajaran reciprocal teaching dipadukan think pair share terhadap peningkatan kemampuan metakognitif belajar biologi siswa SMA berkemampuan akademik berbeda di kabupaten sidoarjo. Jurnal Santiaji Pendidikan (JSP), 3(2), 85-109.

[5]. Rinjani, D. M., Raksun, A., \& Artayasa, I. P. 2010. Penerapan Model Reciprocal Teaching Untuk Meningkatkan Prestasi Belajar Biologi Siswa Kelas X Di SMAN 4 Mataram Tahun Ajaran 2008/2009. Jurnal Pijar Mipa, 5(1).

[6]. Mulyono, D., Asmawi, M., \& Nuriah, T. 2018. The Effect of Reciprocal Teaching, Student Facilitator and Explaining and Learning Independence on Mathematical Learning Results by Controlling the Initial Ability of Students. International Electronic Journal of Mathematics Education, 13(3), 199-205.

[7]. Ibrahim. 2007. Penelitian dan Penilaian Pendidikan. Bandung: Sinar Baru Algesindo.

[8]. Hosnan, M. 2014. Pendekatan Saintifik dan Kontekstual Dalam Pembelajaran Abad 21. Bogor: Ghalia Indonesia.

[9]. Hadi, A.N. 2009. Pengaruh Penerapan Strategi Pembelajaran Problem Base Learning (PBL) terhadap Ketrampilan Metakognitif dan pemahaman konsep siswa klas X di SMA Negeri 8 Malang pada kemampuan Akademik Berbeda. Jurnal Inkuiri. 1, 2. 
[10]. Gayatri, I. G. A. S., Jekti, D. S. D., \& Jufri, A. W. 2013. Efektifitas pembelajaran berbasis masalah (PBM) dan strategi kooperatif terhadap kemampuan menyelesaikan masalah dan hasil belajar kognitif biologi ditinjau dari kemampuan akademik awal siswa kelas $\mathrm{X}$ SMA Negeri 3 Mataram. Jurnal Pijar Mipa, 8(2).

[11]. Muhiddin, P. 2012. Pengaruh Integrasi PBL dengan Pembelajaran Kooperatif Jigsaw dan Kemampuan Akademik terhadap Metakognisi, Berpikir Kritis, Pemahaman Konsep, dan Retensi Mahasiswa pada Perkuliahan Biologi Dasar di FMIPA Universitas Negeri Makassar. Jurnal Penelitian Pendidikan InsaniI. 13.
[12]. Laksmiwati, D., Hadisaputra, S., \& Siahaan, J. (2019). Pengembangan Modul Praktikum Kimia Berbasis Problem Based Learning Untuk Kelas XI SMA. Chemistry Education Practice, 1(2), 36-41.

[13]. Suharlik, 2011. Pengaruh Strategi Pembelajaran Integrasi TPS dan RT terhadap Hasil Belajar Kognitif dan Retensi Biologi Siswa Berkemampuan Akademik Berbeda di SMAN 1 Batu. E-Journal Fakultas MIPA Universitas Negeri Malang. 12.

[14]. Afandi, Sugiyarto, Sunarno, W. 2012. Pembelajaran Biologi Melalui Model Reciprocal Learning dan Problem Based Learning Ditinjau Dari Kemampuan Belajar dan Berpikir Kritis Mahasiswa. Jurnal Inkuiri. 1, 2. 